Professor C.C. De Silva Memorial Oration - 2016

\title{
Thalassaemia: In a quest towards an ultimate cure
}

Sachith Mettananda ${ }^{1}$

Sri Lanka Journal of Child Health, 2017; 46(3): 203-210

DOI: http://dx.doi.org/10.4038/sljch.v46i3. 8318

(Key words: Thalassaemia, ultimate cure)

Cholomondley Chalmers de Silva was born on the $25^{\text {th }}$ of February 1904 and obtained his primary and secondary education from Bishops College, Government Training College and St. Thomas' College, Mount Lavinia. He obtained MBBS and Doctor of Medicine degrees from University of London and was a member of the Royal College of Physicians in London. Following his return to Sri Lanka, in 1949, he joined the Faculty of Medicine of the University of Ceylon as the first Professor of Paediatrics. He was instrumental in developing the Department of Paediatrics at the Faculty of Medicine and the Professorial Paediatrics Unit at the Lady Ridgeway Children's Hospital, Colombo.

Professor C.C. de Silva was an excellent clinician, teacher, administrator and a researcher. His tireless work as a clinician undoubtedly helped in combating malnutrition in Sri Lanka. He established the Malnutrition Clinic at the Lady Ridgeway Children's Hospital in 1956 and moving further established the Thalagolla Convalescent Home for malnourished children which still serves children with nutritional deficiencies and special social needs.

He was a reputed academic both locally and internationally. He has numerous highly cited publications in many high impact journals of his time. One of his main research interests was haemoglobinopathies and in fact it is his pioneering work which led to the description of the first Sri Lankan child with thalassaemia in a paper published in Archives of Disease in Childhood way back in $1951^{1}$. Ladies and gentlemen, it is indeed a great pleasure to talk to you today on a novel approach to cure thalassaemia as a tribute to the very first

${ }^{1}$ Senior Lecturer, Department of Paediatrics, Faculty of Medicine, University of Kelaniya, Sri Lanka and Consultant Paediatrician, Colombo North Teaching Hospital, Ragama, Sri Lanka

Correspondence:sachithmetta@yahoo.com, sachith.mettananda@kln.ac.lk

The author declares that there are no conflicts of interest

Open Access Article published under the Creative

Commons Attribution CC-BY (cc) License clinician who described the disease in Sri Lankan children.

\section{Introduction}

Thalassaemia is one of the most common genetic disorders in the world ${ }^{2}$. It is estimated that nearly 70,000 children are born worldwide with thalassaemia each year of which a majority have transfusion dependent $\beta$-thalassaemia ${ }^{3}$. Most of these births occur in the traditional 'thalassaemia belt' which extends from Mediterranean, subSaharan Africa through Middle East to South and South-east Asia. However due to recent migration patterns thalassaemia has become an increasing health, financial and social problem to most countries in the world.

Thalassaemia has been a long-standing health problem in Sri Lanka, too. Thanks to the pioneering work done by several Paediatricians, Physicians and Scientists in the past, the burden of thalassaemia in Sri Lanka has been well studied and reported. The prevalence of $\beta$-thalassemia carrier state in Sri Lanka is reported as $2.5 \%$, and we, as paediatricians, care for approximately 3,000 patients with transfusion dependent thalassaemia in the country. It is estimated that $60-80$ new patients with thalassaemia are born each year. Therefore, thalassaemia still presents a great burden to the health care system of Sri Lanka ${ }^{4,5}$.

Patients with $\beta$-thalassaemia present in infancy with pallor, growth failure, hepatosplenomegaly and characteristic bone changes ${ }^{6}$. They have severe anaemia which is invariably fatal without treatment. These patients require regular monthly red blood cell (RBC) transfusions to maintain their haemoglobin at safe levels. Regular transfusions carry significant risks and lead to numerous complications including iron overload, which is the most troublesome. Excess iron gets deposited in body organs including heart, liver, pancreas, and endocrine organs and results in organ dysfunction and failure. Even though three iron chelating medications are currently available to treat iron overload, none has been efficacious enough to produce optimal results. Therefore, patients with $\beta$ thalassaemia still experience a relatively poor quality of life and die prematurely. The current 
standard treatment, despite being extremely costly, provides only supportive care and is not curative ${ }^{2}$.

The only curative treatment option available for the patient with $\beta$-thalassaemia is allogeneic bone marrow transplantation $(\mathrm{BMT})^{7}$. However, this has several limitations. Firstly, BMT is routinely available only to a minority of patients who have suitable donors. Secondly, it is associated with a number of serious adverse events, for instance graftvs-host disease which can be life-threatening ${ }^{8}$. Thirdly, in developing countries like Sri Lanka, the cost of BMT is far beyond the limits of what most people can afford. Hence it is clear that there is a great need for new, alternative and effective therapeutic strategies for treatment of this life limiting disease. Ladies and gentlemen, in this oration I am presenting the findings of my journey in search of a possible 'cure' for $\beta$-thalassaemia.

\section{Rationale and hypothesis}

An understanding of the basic pathophysiology of $\beta$ thalassaemia is required to appreciate the rationale of the work presented here. In brief, adult human haemoglobin is composed of two $\alpha$ - and two $\beta$ globin polypeptide chains which are encoded by $\alpha$ and $\beta$-globin genes respectively. In patients with $\beta$ thalassaemia, due to mutations in the $\beta$-globin gene, the production of $\beta$-globin is either reduced or absent to result in a reduction in the amount of adult haemoglobin. However, the synthesis of $\alpha$-globin continues normally and this unopposed production leads to an accumulation of $\alpha$-globin within the red blood cell (RBC). These insoluble $\alpha$-globin chains precipitate in RBCs and their precursors to result in haemolysis and ineffective erythropoiesis (Figure $1)^{9}$. RBC destruction by these mechanisms is the main factor leading to anaemia in patients with $\beta$ thalassaemia ${ }^{6}$.

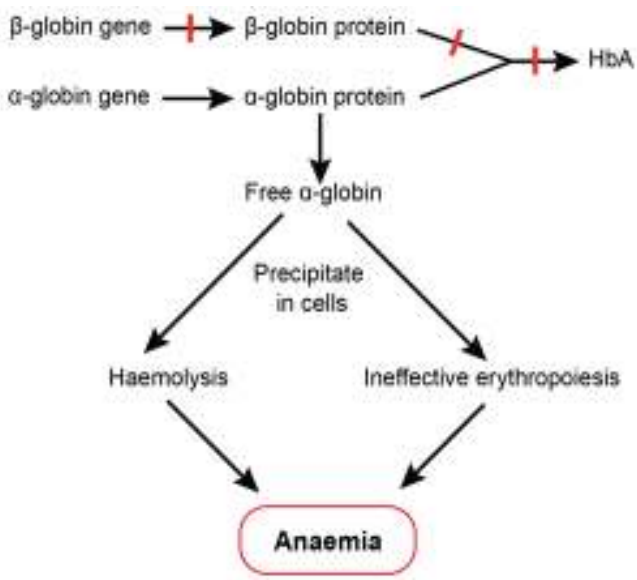

Figure 1: Pathophysiology of $\beta$-thatassaemia

Therefore, we hypothesised that if we can control the production of $\alpha$-globin in patients with $\beta$ thalassaemia, it should reduce the excess of $\alpha$-globin and destruction of RBC and should lower the severity of anaemia. This should invariably ameliorate the severity of $\beta$-thalassaemia and reduce or in fact eliminate the need for blood transfusions in these patients.

Natural reduction of $\alpha$-globin in patients with $\beta$ thalassaemia

As the first step in validating this hypothesis we examined the occurrence of this phenomenon in nature. Four copies of $\alpha$-globin gene are present in each human cell and natural reduction of $\alpha$-globin is seen in patients with $\alpha$-thalassaemia. Depending on the number of mutated $\alpha$-globin genes, the clinical severity of $\alpha$-thalassaemia varies. Deletion of a single $\alpha$-globin gene is asymptomatic and deletion of two genes results in mild microcytic anaemia. Deletion of 3 out of $4 \alpha$-globin genes leads to Haemoglobin $\mathrm{H}$ disease whereas deletion of all $4 \alpha-$ globin genes results in a fatal disease known as Haemoglobin Barts hydrops fetalis (Table 1$)^{10}$.

Table 1: Correlation of clinical severity with the number of mutated $\alpha$-globin genes

\begin{tabular}{|c|c|c|}
\hline No. of mutated $\alpha$-globin genes & a-globin genotype & Clinical phenotype \\
\hline 0 & $\alpha \alpha / \alpha \alpha$ & Normal \\
\hline 1 & $-\alpha / \alpha \alpha$ & 'Silent' $\alpha$-thalassaemia \\
\hline 2 & $-\alpha /-\alpha$ or $--/ \alpha \alpha$ & $\alpha$-thalassaemia trait \\
\hline 3 & $--/-\alpha$ & Haemoglobin H disease \\
\hline 4 & $--/--$ & Haemoglobin Bart's hydrops fetalis \\
\hline
\end{tabular}

Because of the higher prevalence of $\alpha$-thalassaemia and $\beta$-thalassaemia in some parts of the world, both these diseases can coexist. There are several case reports, case-control and cohort studies which described patients who co-inherit $\alpha$ - and $\beta$ thalassaemia. These studies have very well demonstrated that the presence of $\alpha$-thalassaemia with deletions of one or two $\alpha$-globin genes is associated with a milder disease in most patients with $\beta$-thalassaemia with older age at presentation, smaller splenic and hepatic sizes, normal physical and sexual maturation, less severe anaemia and significantly reduced transfusion requirements compared to patients with normal $\alpha$-globin genes ${ }^{11}$. Furthermore, these studies have highlighted that a reasonable proportion of patients with $\beta$ thalassaemia who co-inherit $\alpha$-thalassaemia are completely asymptomatic and live normal lives in 
the community without coming to medical attention at all ${ }^{12,13}$. The $\alpha$-globin gene deletions decrease the $\alpha$-globin excess in RBCs of patients with $\beta$ thalassaemia thus reducing haemolysis and ineffective erythropoiesis leading to less severe anaemia.

We published these findings in a recent review article in 'Blood' where we concluded that a reduction of $\alpha$-globin levels by $25 \%-50 \%$ in patients with $\beta$-thalassaemia should reduce or in fact eliminate the need of blood transfusion and could lead to a possible 'cure'14. However, to use this phenomenon as a therapeutic tool, we need to selectively reduce the production of $\alpha$-globin without affecting the production of $\beta$-globin. Is this possible? If so how? Those were the two main questions which we had to find answers for.

\section{Regulation of $\alpha$-globin gene}

To answer above questions, we need to understand the regulation of the expression of the $\alpha$-globin gene. Any human gene is controlled by three inter-related mechanisms namely, enhancers, transcription factors and epigenetic mechanisms (Figure 2). With regards to the regulation of $\alpha$-globin gene, enhancers and epigenetic mechanisms are the two most important regulatory mechanisms ${ }^{15}$.

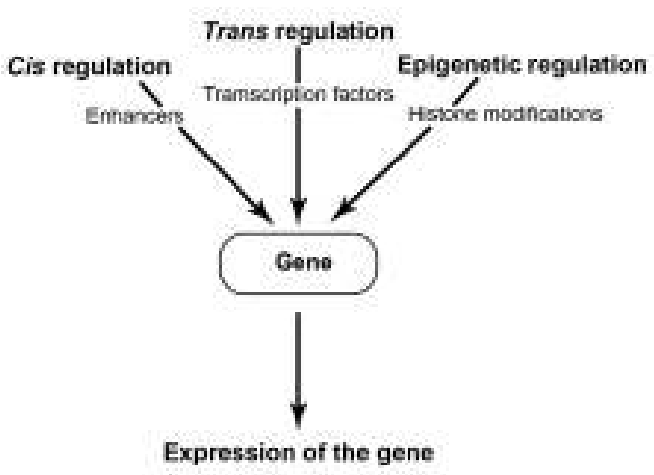

Figure 2: Regulation of expression of human genes

What are these enhancers? For those who are not familiar with genetics and molecular medicine, enhancers are DNA sequences that facilitate the transcription of genes. Transcription of the gene is the first step leading to the production of the specific protein encoded by that gene inside human cells. In terms of $\alpha$-globin, a number of studies have identified a DNA sequence that is in the same chromosome as of $\alpha$-globin to function as the main enhancer of $\alpha$-globin (Figure 3$)^{16}$. This is known as MCS-R2. There are case reports of patients who have deletions limited to this enhancer resulting in $\alpha$-thalassaemia despite having perfectly normal $\alpha$ globin genes confirming that an intact MCS-R2 enhancer is critical for the normal production of $\alpha$ globin in human $\mathrm{RBCs}^{10}$.

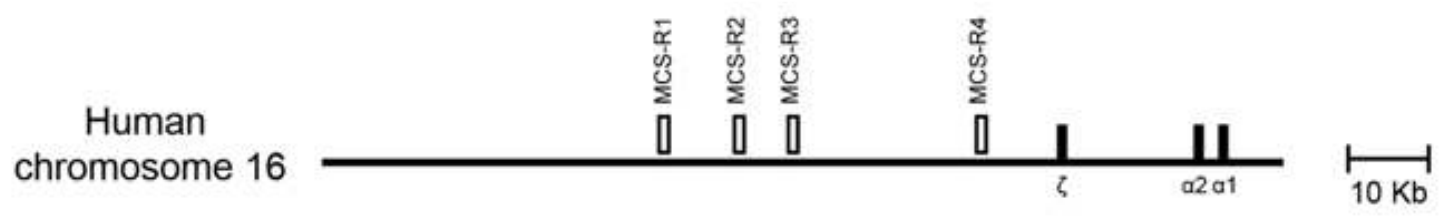

\section{I globin genes Enhancers of $\alpha$-globin genes}

\section{Figure 3: Schematic diagram of human a-globin gene locus and its associated cis-acting enhancers}

As previously stated, the other important regulatory mechanism governing the expression of $\alpha$-globin gene is epigenetic regulation. Again for those who are not familiar, epigenetics explain how cells in a multicellular organism have identical DNA sequences, yet maintain different phenotypes ${ }^{17}$. In a simpler way; we know that every human cell has all the genes required to produce all the proteins which are essential for the human body. However, only a limited number of essential and relevant proteins are produced in each human cell. For example, globin genes are present in all human cells including the brain, muscle and intestinal cells. However, haemoglobin is only produced in RBCs and is never produced in brain, muscle or intestinal cells. The reason behind this is that in non-erythroid cells, globin genes are silenced through chemical modifications of DNA and histone proteins. These silencing mechanisms are known as epigenetics or epigenetic regulation.

Next, we reviewed the understanding of the regulation of the $\alpha$-globin gene which is published in 'Annals of New York Academy of Science'18. In this we concluded that in human RBCs, $\alpha$ - and $\beta$ globin genes are regulated by independent enhancers and different epigenetic mechanisms. Then we proposed to utilise these differences to reduce the production of $\alpha$-globin without affecting the production of $\beta$-globin. 


\section{Development of an in-vitro model to test new therapies}

The first hurdle was to decide on a platform to test these experimental therapies. Can we test these straight in humans? Or in animals? The definite answer is 'no'. None of the innovative therapies for human diseases can be tested directly on humans or animals. They must be first tested in pre-clinical invitro models - i.e. human cells in laboratories before proceeding into animal experiments and phase I clinical trials in humans.

Therefore, we initially tested our experimental therapies in human cells and for this, we developed an erythroid cell culture system using human peripheral blood. In this system the haematopoietic stem cells were separated out from blood samples using the technique known as magnetically activated cell sorting and these cells were then grown in the laboratory in an erythropoietin containing growth medium until they are expanded in numbers to produce large number of daughter cells. The morphological characteristics of the cells generated in the laboratory, over 21 days, showed gradual differentiation of stem cells into RBCs mimicking normal human erythropoiesis within the bone marrow.

Pharmacological approach - epigenetic therapies Next, using this culture system we embarked on a search for a drug that would reduce the production of $\alpha$-globin without affecting the production of $\beta$ globins. When we reviewed the understanding of the regulation of $\alpha$-globin gene it was apparent that the epigenetic differences are the most suitable target to develop drug therapies. Therefore, we decided to test a group of drugs which are known as epigenetic drugs. Epigenetic drugs act at different epigenetic pathways and some of these have been approved by the Food and Drug Administration (FDA) of the United States for clinical use and many others are currently in clinical trials ${ }^{19}$.

We treated erythroid cells with several epigenetic drugs in tissue culture plates and evaluated the production of $\alpha$-and $\beta$-globin in cells using real-time PCR. The primary screening criterion was downregulation of $\alpha$-globin expression without altering $\beta$ globin expression and an $\alpha / \beta$ globin mRNA ratio of less than 0.75 was considered as the cut-off for identifying high-scoring compounds. Result of this experiment is published in 'Haematologica' and is summarised in Table $2^{20}$. This screen identified four compounds that down regulate $\alpha$-globin expression: histone demethylase inhibitor, IOX1; histone deacetylase inhibitor, vorinostat; histone methyltransferase inhibitor, chaetocin and lysinespecific histone demethylase 1 inhibitor, tranylcypromine. Out of these four compounds, a novel epigenetic compound which is known as IOX1 showed the most promising results with the lowest $\alpha$-globin levels. IOX1 is an epigenetic inhibitor drug which inhibits histone demethylase enzymes which are responsible for the removal of methyl groups from histone proteins. It is a new chemical entity which is not yet approved by the FDA nor entered into clinical trials ${ }^{21}$.

We then tested the effects of a dose range of IOX1 on the expression of $\alpha$ - and $\beta$-globin genes. This showed that IOX1 significantly reduces production of $\alpha$-globin in a dose dependent manner (Figure 4).

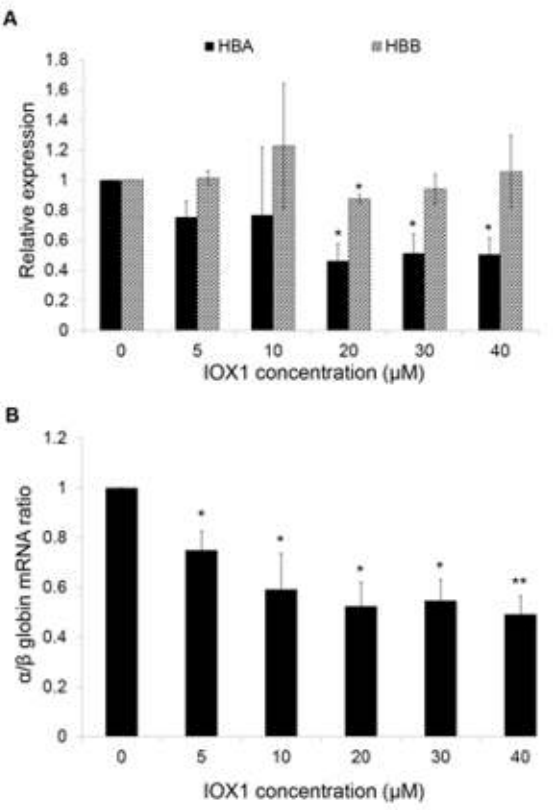

Figure 4: Effects of IOX1 on $\alpha$-and $\beta$-globin gene expression in human erythroid cells. (A) $\alpha$-and $\beta$-globin expressions (B) $\alpha / \beta$ globin $m R N A$ ratios

In both graphs mean expression values from 3 independent biological repeats are shown; error bars represent standard deviation; ${ }^{*} p<0.05$ and ${ }^{* *} p<0.01$ relative to $0 \mu M$ concentration Abbreviations: $H B A, \alpha$-globin; $H B B, \beta$-globin

There was no effect on the production of $\beta$-globin suggesting that IOX1 has specific action on $\alpha$-globin but not $\beta$-globin. Then we evaluated for possible adverse effects of IOX1 on erythroid cells. Cells treated with IOX1 were morphologically and immuno-phenotypically similar to untreated cells confirming that treatment of IOX1 does not alter the differentiation of erythroid cells. Also, the expression levels of most other genes in the erythroid cells treated with IOX1 were similar to the untreated cells. These observations confirm that IOX1 selectively reduces production of $\alpha$-globin without altering the production of $\beta$-globin. IOX1 does not have adverse effects on RBC differentiation or expression of other genes suggesting that it is a suitable candidate drug to reduce production of $\alpha$ globin in patients with $\beta$-thalassaemia ${ }^{20}$. 
Table 2: $\alpha / \beta$ globin ratios in cells treated with epigenetic drugs compared to untreated cell

\begin{tabular}{|c|c|c|c|}
\hline Epigenetic inhibitor & $\begin{array}{c}\text { Mean } \alpha / \beta \text { globin ratio } \\
\text { (compared to untreated) } \\
n=3\end{array}$ & Standard deviation & $\begin{array}{c}\text { p value } \\
\text { (compared to untreated) }\end{array}$ \\
\hline CXD101 & 3.25 & 0.21 & 0.04 \\
\hline$(+)-J Q 1$ & 6.45 & 1.55 & 0.03 \\
\hline (-)- JQ1 & 1.30 & 0.10 & 0.04 \\
\hline PFI-1 & 2.47 & 1.70 & 0.27 \\
\hline CBP/BRD4(0383) & 1.36 & 0.67 & 0.45 \\
\hline UNC0638 & 3.12 & 0.76 & 0.04 \\
\hline IOX1 & 0.37 & 0.03 & $0.02 *$ \\
\hline IOX2 & 1.03 & 0.11 & 0.71 \\
\hline 5-Azadeoxycytidine & 3.34 & 2.01 & 0.18 \\
\hline Sodium Valproate & 1.57 & 0.78 & 0.33 \\
\hline K00135 & 0.74 & 0.27 & 0.24 \\
\hline SMARCA & 0.91 & 0.15 & 0.39 \\
\hline I-BET & 2.55 & 0.64 & 0.05 \\
\hline Rucaparib & 3.34 & 1.31 & 0.09 \\
\hline BAZ2B & 1.19 & 0.12 & 0.11 \\
\hline Chaetocin & 0.64 & 0.04 & $0.05 *$ \\
\hline 5-Iodotubercidin & 1.07 & 0.59 & 0.86 \\
\hline Olaparib & 1.14 & 0.59 & 0.73 \\
\hline Entinostat & 1.09 & 0.59 & 0.81 \\
\hline Trichostatin A & 1.70 & 0.24 & 0.15 \\
\hline Vorinostat & 0.70 & 0.42 & 0.50 \\
\hline Methylstat & 1.75 & 0.42 & 0.09 \\
\hline Bromosporin & 1.54 & 0.21 & 0.05 \\
\hline CBP probe $(0113)$ & 2.23 & 0.88 & 0.14 \\
\hline RVX-208 & 1.12 & 0.23 & 0.47 \\
\hline SRT1720 & 1.22 & 0.77 & 0.67 \\
\hline EX527 & 1.23 & 0.33 & 0.35 \\
\hline GSK343 & 1.84 & 1.14 & 0.33 \\
\hline C646 & 1.23 & 0.55 & 0.55 \\
\hline Sodium butyrate & 2.85 & 1.14 & 0.11 \\
\hline Tranylcypromine & 0.67 & 0.13 & $0.04 *$ \\
\hline SGC0946 & 0.98 & 0.33 & 0.94 \\
\hline UNC1215 & 0.87 & 0.57 & 0.73 \\
\hline SET7/9-1 & 0.91 & 0.07 & 0.15 \\
\hline SET7/9-2 & 0.89 & 0.29 & 0.58 \\
\hline SET7/9-3 & 1.24 & 0.26 & 0.25 \\
\hline
\end{tabular}

*Drugs which show significant reductions in $\alpha$-globin levels

\section{Genome editing approach}

Another approach that can be used to reduce the $\alpha$ globin is genome editing. Genome editing using sequence-specific programmable artificially engineered nucleases has not only revolutionized biomedical research as powerful tools for investigating gene regulation but also provides a realistic approach to the treatment of human genetic diseases. The most recent and novel method of genome editing is by using clustered, regularly interspaced, short palindromic repeat (CRISPR) system. CRISPR genome editing technology was developed in the year 2013 and is considered to be one of the greatest recent inventions in medicine. Discovery of this technique has led to thousands of high impact publications within a very short period $^{22}$. The basic principle of CRISPR genome editing technique is to mutate a specific gene by cutting at a pre-determined target site in the human genome, commonly creating a deletion within the gene. In simple terms CRISPR reagents act as molecular scissors.

As described previously, MCS-R2 is the most important enhancer of the human $\alpha$-globin gene and is crucial for normal $\alpha$-globin production in RBCs. There are case reports of patients with deletions confined to this MCS-R2 region causing $\alpha$ thalassaemia despite having normal $\alpha$-globin genes. For example, a previously described Portuguese patient has a homozygous deletion confined to the MCS-R2 enhancer and has $\alpha$-thalassaemia haemoglobin $\mathrm{H}$ disease ${ }^{23}$.

Therefore, we proposed that if we could create a deletion of the MCS-R2 enhancer by genome editing in human erythroid cells, we would be able to decrease the $\alpha$-globin production to levels beneficial in patients with $\beta$-thalassaemia. The ultimate goal of this approach is to harvest stem cells from patients 
with $\beta$-thalassaemia, genome edit them in laboratories to create a deletion of MCS-R2 enhancer and transplant them back to the same patient as an autologous BMT (Figure 5). Hypothetically, erythroid cells generated from these stem cells should have decreased levels of $\alpha$-globin and a lesser excess of $\alpha$-globin which should lead to reduced RBC destruction and to a potential 'cure' of $\beta$-thalassaemia ${ }^{24}$

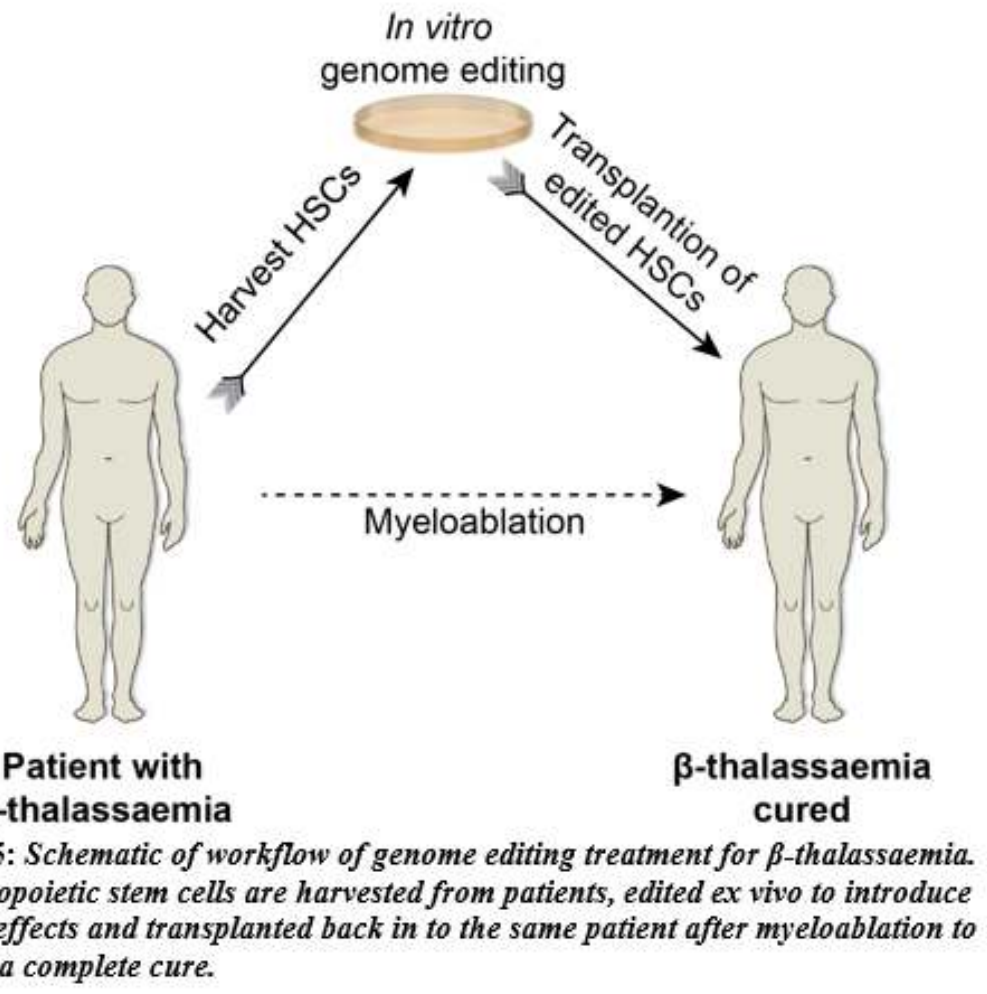

\section{Conclusion}

Ladies and gentlemen, in this oration I presented an extremely novel pathway that could lead to a possible 'cure' of $\beta$-thalassaemia which is still a life limiting disease in a majority. Firstly, we demonstrated that a $25 \%$ to $50 \%$ reduction of $\alpha$ globin production is beneficial and can reduce or eliminate the need for blood transfusions in patients with $\beta$-thalassaemia. Secondly, using a pharmacological approach, we showed that the epigenetic drug IOX-1 significantly reduces the production of $\alpha$-globin in human erythroid cells. Thirdly, we propose the use of CRISPR genome editing tool to create a therapeutic deletion of MCSR2 human $\alpha$-globin enhancer to reduce the production of $\alpha$-globin in human erythroid cell to levels beneficial in patients with $\beta$-thalassaemia. The main advantage of genome editing technology is that it alleviates the need for HLA-matched sibling donors for BMT therefore would be available to all patients with $\beta$-thalassaemia. Similarly, as the transplanted cells are autologous it will eliminate the need for immune-suppression and minimize serious adverse effects of transplantation.
However, several challenges still remain before these genetic remedies become standard therapies for $\beta$-thalassemia. In the pharmacological approach, major optimisations of IOX1 are required before it becomes a suitable medicine to approach clinical trials. Similarly, in genome editing, lack of specificity and the potential for off-target effects of CRISPR genome editing tools still remain as major challenges. Genetic modifications are permanent, and deleterious off-target mutations might create cells with oncogenic potential or functional impairment. To overcome these challenges several new strategies are being developed. With regards to IOX1, chemical optimizations to increase the potency are ongoing and there are bright prospects for development of drugs which have properties similar to IOX1.

From a Sri Lankan perspective, development of pharmacological therapies would be extremely advantageous as it would not require sophisticated technologies and the final products can be imported. Therefore, patients in Sri Lanka would undoubtedly benefit if any research on development of IOX1 as a useful medicine becomes successful. Conversely, if we are to take an advantage from genome editing 
based therapies, basic infrastructure needs to be developed. Firstly, BMT should be freely available, should become a common practice and function optimally. To achieve this, in my opinion, encouragement and every possible support should be extended to the BMT programmes currently functioning in the country and a cost-effective BMT centre should be established in the state sector without delay. In addition, a clinical scale specialised molecular medicine laboratory with basic facilities has to be established.

Once these requirements are met, we will be in a very good position to carry out laboratory and clinical research on thalassaemia at its highest calibre. We will be able to carry out clinical trials for treatment of $\beta$-thalassaemia using IOX1 or other suitable drugs which are being developed. Similarly, we can also contribute to the clinical trials of transplantation of MCS-R2 genome edited stem cells. If successful, patients in Sri Lanka will benefit from cutting-edge genetic based scientific discoveries to 'cure' $\beta$-thalassaemia and would in fact be very first to receive these.

\section{Acknowledgements}

I wish to thank Professor Douglas Higgs and Professor Richard Gibbons for providing supervision throughout my DPhil at University of Oxford. This work would not have been possible without the Commonwealth Scholarship funded by the UK Government. My heartfelt gratitude also goes to Professors Harendra de Silva and Shaman Rajindrajith for their guidance in preparation of this manuscript.

\section{References}

1. de Silva CC, Weeratunge CES. Cooley's anaemia in Sinhalese children. Archives of Disease in Childhood 1951; 26:224-30. https://doi.org/10.1136/adc.26.127.224 PMCid: PMC1988377

2. Higgs DR, Engel JD, Stamatoyannopoulos G. Thalassaemia. Lancet 2012; 379(9813): 373-83. https://doi.org/10.1016/S01406736(11)60 283-3

3. Weatherall DJ. The challenge of haemoglobinopathies in resource-poor countries. British Journal of Haematology 2011; 154(6):736-44.

https://doi.org/10.1111/j.13652141.2011.0 8742.x

PMid:21726207
4. de Silva S, Fisher CA, Premawardhena A, Lamabadusuriya SP, Peto TE, Perera G, et al. Thalassaemia in Sri Lanka: implications for the future health burden of Asian populations. Sri Lanka Thalassaemia Study Group. Lancet 2000; 355(9206):786-91. https://doi.org/10.1016/S01406736(99)08 246-X

5. Mettananda S, de Silva DG. Anaemia in children: are we using the correct prevention strategies? Ceylon Medical Journal 2017; 62(2):73-6.

https://doi.org/10.4038/cmj.v62i2.8469

PMid: 28697539

6. Weatherall DJ, Clegg JB. The thalassaemia syndromes. 4 ed. Oxford: Blackwell Science; 2001.

https://doi.org/10.1002/9780470696705

7. Angelucci E, Matthes-Martin S, Baronciani D, Bernaudin F, Bonanomi S, Cappellini MD, et al. Hematopoietic stem cell transplantation in thalassemia major and sickle cell disease: indications and management recommendations from an international expert panel. Haematologica 2014; 99(5):811-20.

https://doi.org/10.3324/haematol.2013.099 747

PMid: 24790059 PMCid: PMC4008115

8. Rachmilewitz EA, Giardina PJ. How I treat thalassemia. Blood 2011; 118(13):347988.

https://doi.org/10.1182/blood-2010-08300335

PMid: 21813448

9. Ribeil JA, Arlet JB, Dussiot M, Moura IC, Courtois G, Hermine O. Ineffective erythropoiesis in beta-thalassemia. The Scientific World Journal 2013; 2013: 394295.

https://doi.org/10.1155/2013/394295 PMid: 23606813 PMCid: PMC3628659

10. Harteveld CL, Higgs DR. Alphathalassaemia. Orphanet Journal of Rare Diseases 2010; 5:13.

https://doi.org/10.1186/1750-1172-5-13

PMid: 20507641 PMCid: PMC2887799

11. Premawardhena A, Fisher CA, Olivieri NF, de Silva S, Arambepola M, Perera W, et al. Haemoglobin E beta thalassaemia in Sri Lanka. Lancet 2005; 366(9495):1467-70. 
https://doi.org/10.1016/S01406736(05)67 396-5

12. Thein SL, Hesketh C, Wallace RB, Weatherall DJ. The molecular basis of thalassaemia major and thalassaemia intermedia in Asian Indians: application to prenatal diagnosis. British Journal of Haematology 1988; 70(2):225-31.

https://doi.org/10.1111/j.13652141.1988.t b02468.x

PMid: 2903765

13. Cao A, Galanello R, Rosatelli MC. Genotype-phenotype correlations in betathalassemias. Blood Reviews 1994; 8(1):112.

https://doi.org/10.1016/0268960X(94)900 $02-7$

14. Mettananda S, Gibbons RJ, Higgs DR. alpha-Globin as a molecular target in the treatment of beta-thalassemia. Blood 2015; 125(24):3694-701.

https://doi.org/10.1182/blood-2015-03633594

PMid: 25869286 PMCid: PMC4497969

15. Higgs DR, Garrick D, Anguita E, De Gobbi $\mathrm{M}$, Hughes J, Muers $\mathrm{M}$, et al. Understanding alpha-globin gene regulation: Aiming to improve the management of thalassemia. Annals of the New York Academy of Sciences. 2005;1054:92-102.

https://doi.org/10.1182/blood-2015-03633594

PMid: 25869286 PMCid: PMC4497969

16. Hughes JR, Cheng JF, Ventress N, Prabhakar S, Clark K, Anguita E, et al. Annotation of cis-regulatory elements by identification, subclassification, and functional assessment of multispecies conserved sequences. Proceedings of the National Academy of Sciences of the United States of America 2005; 102(28):9830-5.

https://doi.org/10.1073/pnas.0503401102 PMid:15998734 PMCid:PMC1174996

17. Bonasio R, Tu S, Reinberg D. Molecular signals of epigenetic states. Science 2010; 330(6004):612-6.

https://doi.org/10.1126/science.1191078

PMid: 21030644 PMCid: PMC3772643
18. Mettananda S, Gibbons RJ, Higgs DR. Understanding alpha-globin gene regulation and implications for the treatment of beta-thalassemia. Annals of the New York Academy of Sciences 2016; 1368(1): 16-24.

https://doi.org/10.1111/nyas.12988

PMid: 26695885

19. Helin K, Dhanak D. Chromatin proteins and modifications as drug targets. Nature 2013; 502(7472):480-8.

https://doi.org/10.1038/nature12751

PMid: 24153301

20. Mettananda S, Fisher CA, Sloane-Stanley JA, Taylor S, Oppermann U, Gibbons RJ, et al. Selective silencing of alpha-globin by the histone demethylase inhibitor IOX1: a potentially new pathway for treatment of beta-thalassemia. Haematologica 2017; 102(3):e80-e4.

https://doi.org/10.3324/haematol.2016.155 655

PMid: 27810991 PMCid: PMC5394973

21. Hopkinson RJ, Tumber A, Yapp C, Chowdhury R, Aik W, Che KH, et al. 5Carboxy-8-hydroxyquinoline is a broad spectrum 2-oxoglutarate oxygenase inhibitor which causes iron translocation. Chem Sci. 2013; 4(8):3110-7.

https://doi.org/10.1039/c3sc51122g

PMid: 26682036 PMCid: PMC4678600

22. Ledford H. CRISPR, the disruptor. Nature 2015; 522(7554):20-4.

https://doi.org/10.1038/522020a

PMid: 26040877

23. Coelho A, Picanco I, Seuanes F, Seixas MT, Faustino P. Novel large deletions in the human alpha-globin gene cluster: Clarifying the HS-40 long-range regulatory role in the native chromosome environment. Blood Cells, Molecules \& Diseases 2010;45(2):147-53. https://doi.org/10.1016/j.bcmd.2010.05.01 0

PMid: 20580289

24. Mettananda DSG. Ameliorating $\beta$ thalassaemia by manipulating expression of the $\alpha$-globin gene Oxford: University of Oxford; 2015. p. 224 